\title{
Review of Scientific Productions and Mapping the Co-authorship in Scopus Database for Researchers at the Hamadan University of Medical Sciences
}

\author{
Hossein Vakilimofrad (PhD) ${ }^{1}$, Somayyeh Hosseinirad (BSc) ${ }^{2, *}$ \\ ${ }^{1}$ Assistant Professor, Department of Medical Library and Information Sciences, School of Paramedicine , Hamadan \\ University of Medical Sciences, Hamadan, Iran \\ ${ }^{2}$ MSc Student, Department of Library and Information Science, School of Paramedicine, Hamadan University of Medical \\ Sciences, Hamadan, Iran
}

* Corresponding Author: Somayyeh Hosseinirad, Department of Library and Information Science, School of Paramedicine, Hamadan University of Medical Sciences, Hamadan, Iran. Tel: 08138398430; Email: s.hosseinirad90@gmail.com

Received: 04/12/2017
Accepted: 26/05/2018
How to Cite this Article:
Vakilimofrad H, Hosseinirad S.
Review of Scientific Productions
and Mapping the Co-authorship
in Scopus Database for Resear-
chers at the Hamadan University
of Medical Sciences. Pajouhan
Scientific Journal. 2018; 16(4):
53-63. DOI: 10.29252/psj.16.
4.53

\section{Abstract}

Background and Objectives: One of the most common methods for assessing the academic activities in a university is the scientometrics that is performed by using citation databases. The present study examined the amount of scientific publications and the co-authorship of the researchers of Hamadan University of Medical Sciences based on scientific articles indexed in the Scopus citation database.

Materials and Methods: This study is a scientometrics research. The statistical population includes the total scientific output of faculty members of Hamadan University of Medical Sciences in the Scopus databases during 2010-2015. The data are collected through a search on the Scopus citation database and the CiteSpace software has been used to drawing a coauthorship map.

Results: Scientific outputs and citations of researchers have grown well in the last five years, but the value of h-index is not in desirable proportions in comparison to the increasing citations. The results of m-index showed that the members who have just begun their academic activity in terms of scientific production have been more active than other members with a history. Compared to other colleges, health and medical schools have the highest number of co-authorship and overall, co-authorship has grown well (Average cooperation coefficient $=0.39$ ) during the years of study.

Conclusions: According to the low amount of participation, we suggest to create a framework for the wider participation between researchers, linking key authors with the other scholars and attracting young researchers.

Keywords: Co-authorship; Compilation; Hamadan University of Medical Sciences; Scientometrics; Scopus 
doi): $10.29252 /$ psj.16.4.53

مقاله مرورى

\section{بررسى كمى توليدات علمى و ترسيم نقشه همنويسندى يخوهشكران دانشكاه علوم

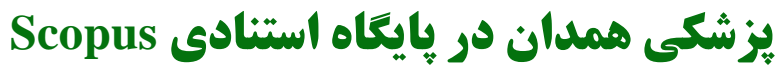

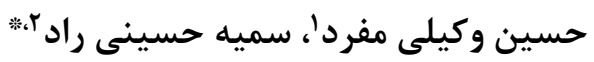

' استاديار، كروه كتابدارى و اطلاع رسانى يزشكى، دانشكده يِيرايزشكى، دانشعاه علوم يزشكى همدان، همدان، ايران

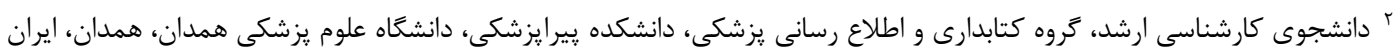
* * نويسنده مسئول: سميه حسينى راد، گروه كتابدارى و اطلاع رسانى :زشكى، دانشكده پِيرايزشكى، دانشكاه علوم يزشكى همدان، همدان، ايران.

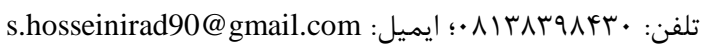

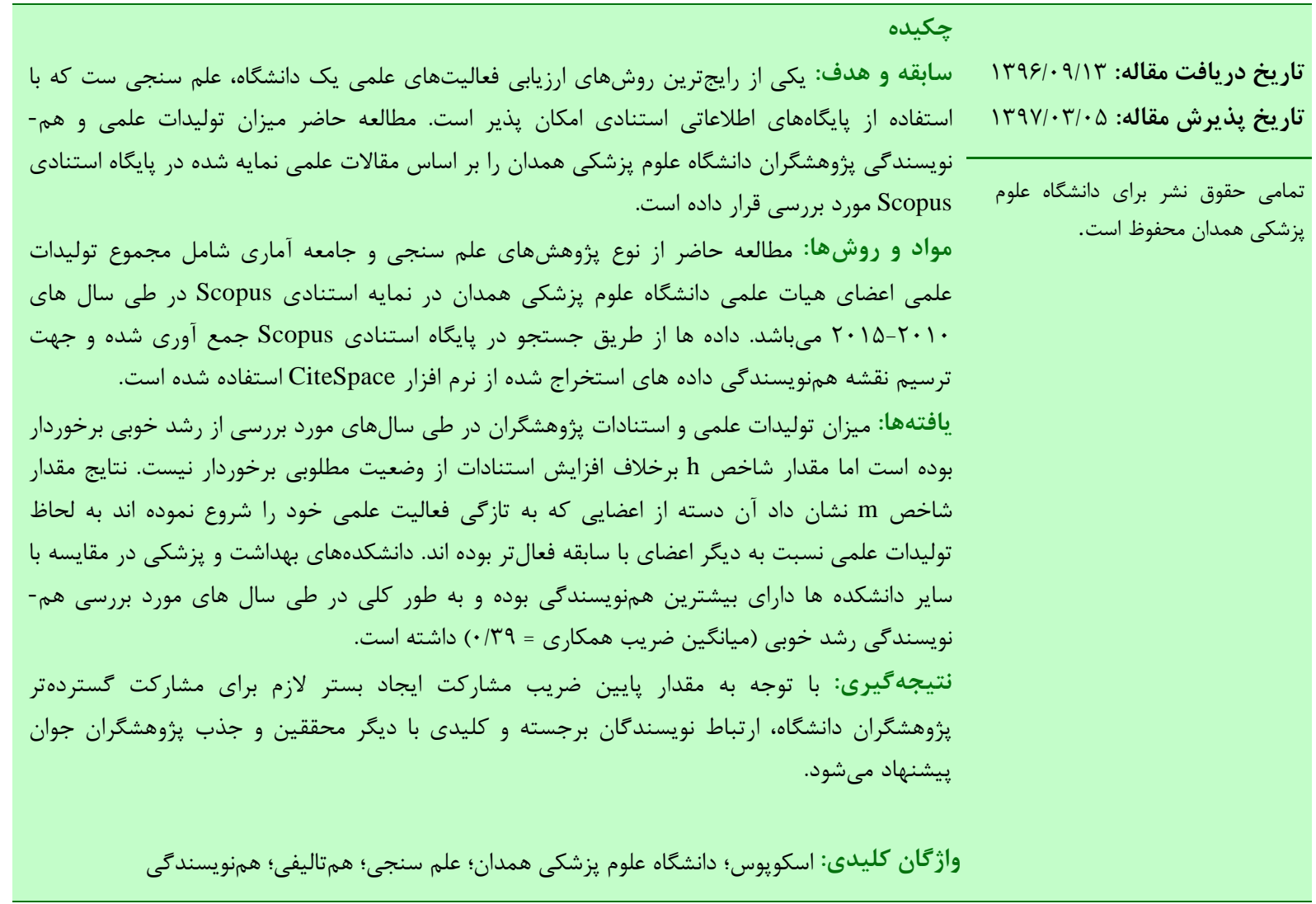

مقدمه

استفاده از شاخصهاى مربوطه مىيردازد و با ارائه تركيبى

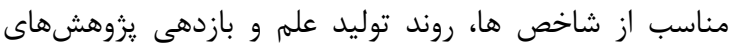

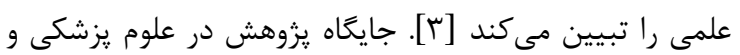

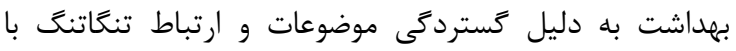

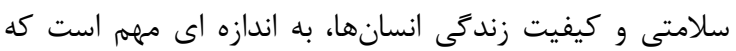

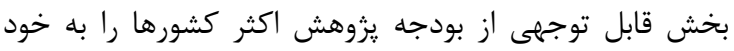

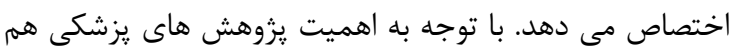

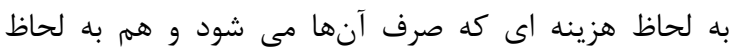

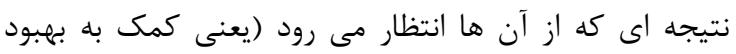

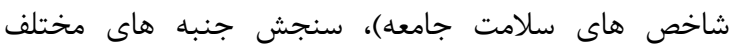

سنجش و ارزيابى علم واقعيتى است كه در كذشته و حال

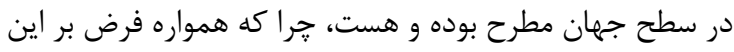

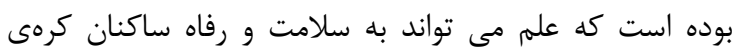
زمين كمك كند [1]]. مجامع علمى همواره به به دنه دنبال شاخصهايى بودهاند كه وضعيت بيشرفت علم را بسنجند و با ماندين

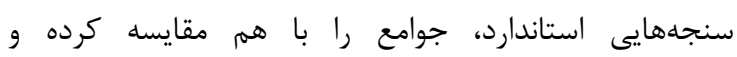

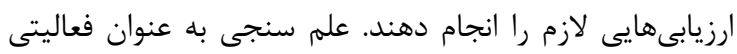

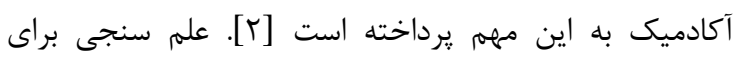

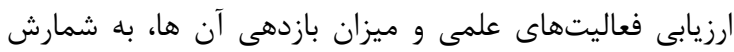
تعداد توليدات علمى در زمينههاى مختلف و تحليل آنهي آنها بان بان 
تعامل است كه امكان ارتباط موثر و نيز سهيم شدن در قابليت

ها و ساير منابع را مى دهد [11]

يكى از نمودهاى بارز همكارى علمى، هم نويسندگ استى است؛

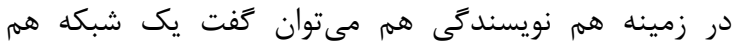

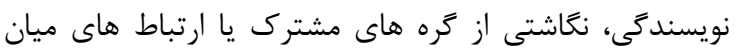
هم نويسنده هاى درون يك جامعه يزوهش است؛ جنين شئ شبكه

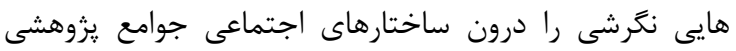
فراهم و آشكار مى كنند كه كدام نويسندكان همكار در فرايند ارتباطات در شبكه داراى نقش مركزى بوده، قدرت و و تاثير

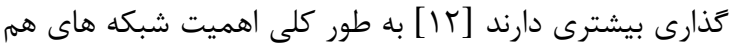

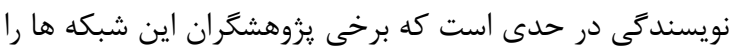

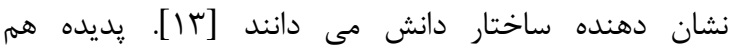

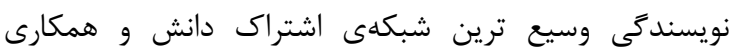

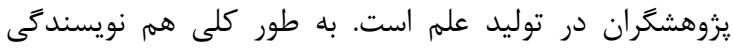

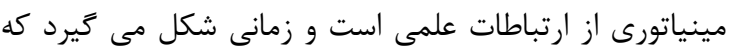
دو يا جند نويسنده با يكديخر همكارى مى كنند. اين همكارى

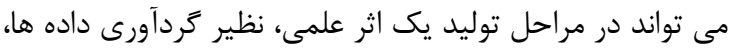

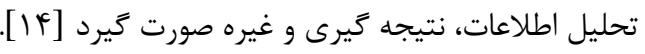

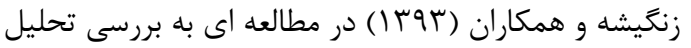

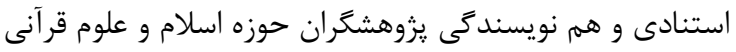

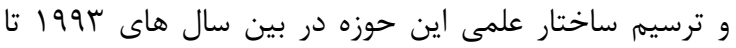

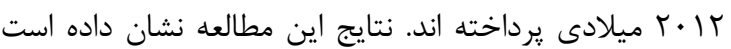
كه همكارى ميان نويسندكان اين حوزه، ضعيف است [10].

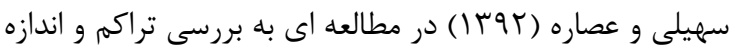
شبكه اجتماعى موجود در شبكه هم نويسندگى مجلات علم رلم

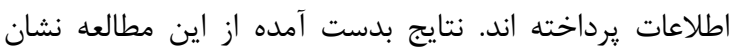
داده است كه مجله انفورماتيك يزشكى آمريكا با تراكم شبكه r/• داراى بالاترين تراكم شبكه هم نويسندكى است و و تبادل

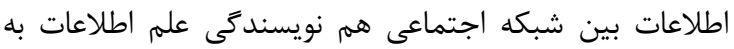
كندى صورت مى

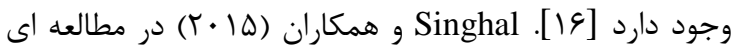

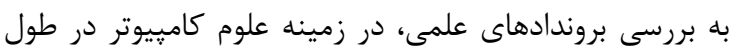

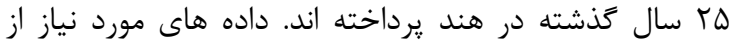

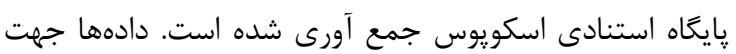
مشخص نمودن كل بروندادهاى علمى، استنادات، الكوهاى همكارى، موسسات و نويسندگان برتر تجزيه و تحليل شده اند.

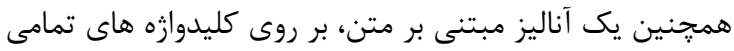

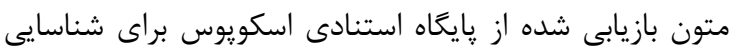

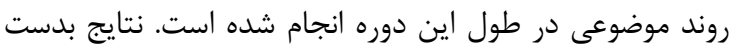

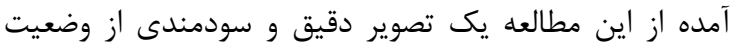

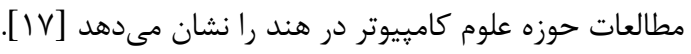
هدف از انجام اين مطالعه شناخت كمى توليدات علمى و ومئو

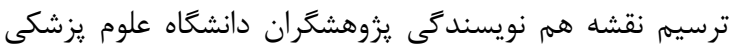

يروهش براى هر نظام آموزش و يزوهش يزشكى بسيار اهميت

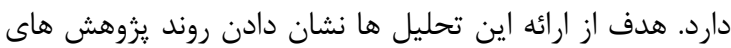

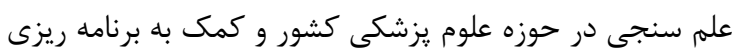
براى تحقيقات سنجش علم يزوهش در حوزه علوم يزشكى و

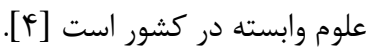
از مهم ترين منابع ابزارهاى موجود در زمينه اين كونه

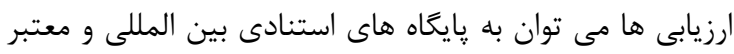

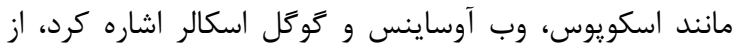
اين ميان پايگاه اسكويوس (از محصولات ناشر معتبر و و بين

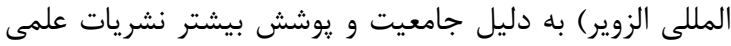

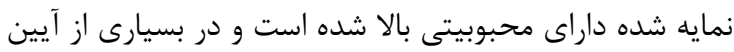

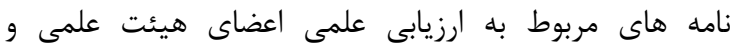
يزوهشكران محافل دانشخاهى (از جمله آيين نامههاى ارتقاى

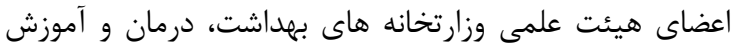

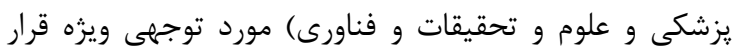

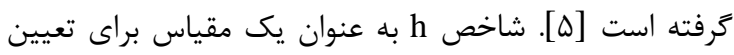

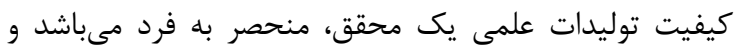

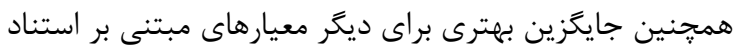

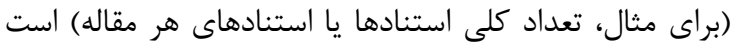

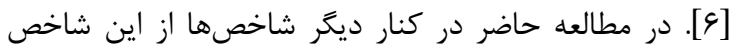

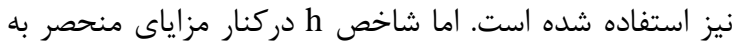

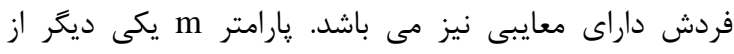

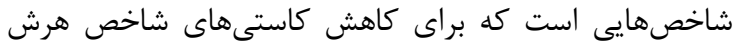

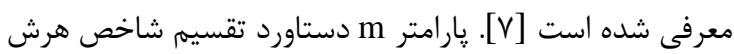

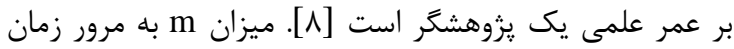

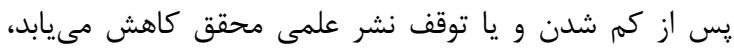

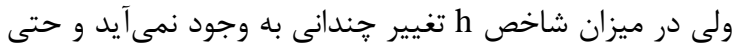

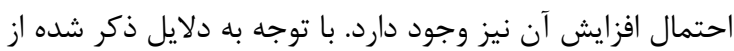
اين شاخص نيز در مطالعه استفاده شده است.

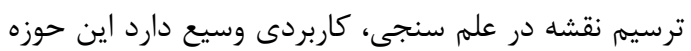

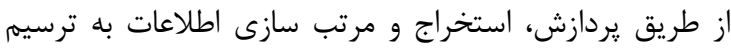

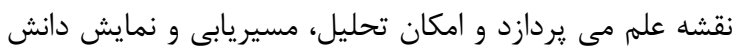

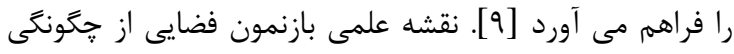

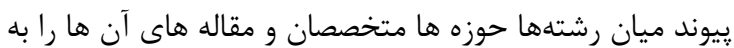

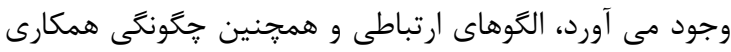

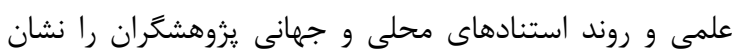

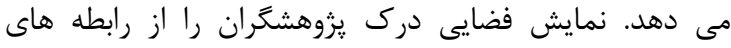

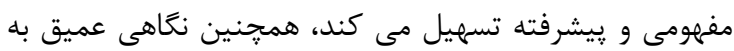

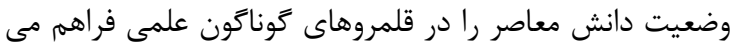

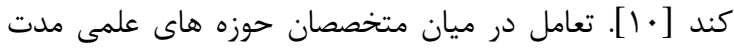

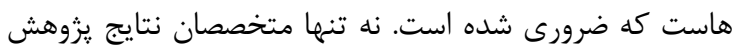

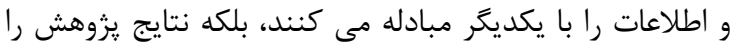
به صورت مشترك توليد مى كنند. همكارى شكل قوى اى از 
تصعداد مدارك داراى j نويسنده كه در دورهى زمانى :Fj

$$
\text { مشخصى در يك زمينه منتشر شده اند }
$$

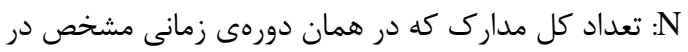

$$
\text { آن زمينه منتشر شده اند }
$$

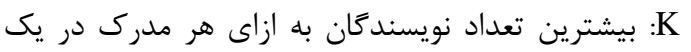

$$
\text { زمينه [119، }
$$

همجنــين مقـالات اعضــاى هيـات علمسى دانشــاه علـوم يزشكى همدان با جستجوى هر دو آدرس وابسـتخى سـازمانى مئى

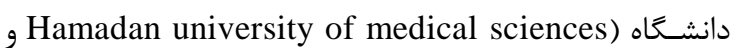
(Hamadan university of medical sciences جستجوى وابسـتكى سـازمانى در يايخـاه Scopus بـا اعمـال

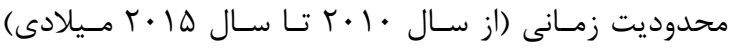

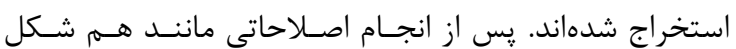
كردن تمامى اسم هاى يك نويسنده، جهت انجام تحليلهـا و و

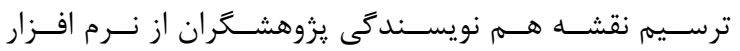

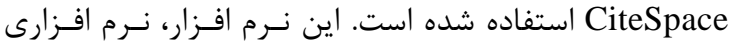
تخصصى براى تحليل هاى علم سنجى است كه با اسـتفاده از

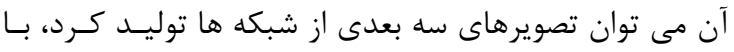

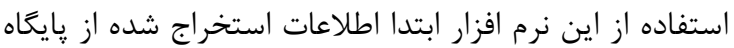

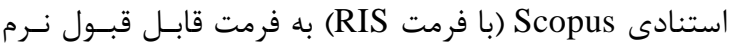

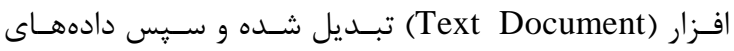

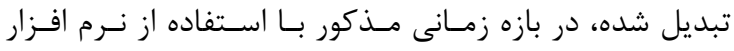
CiteSpace 5.0.R2 (32-bit)

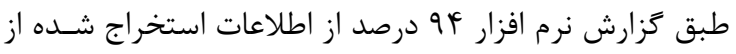

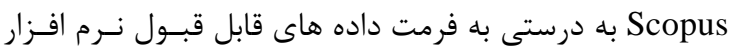

\section{يافتهها}

طبق گزارش معاونت آموزشى در خرداد ماه سال ه9 تعداد

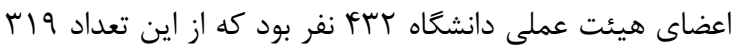
نفر از اعضا طبق جسـتجوهاى انجـام شــده داراى مقالـه نمايسه

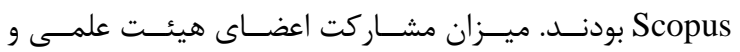

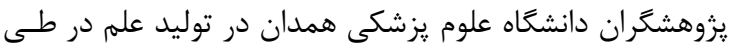

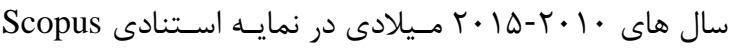

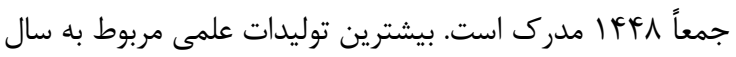

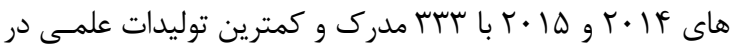

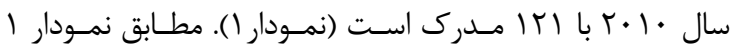
ميزان مقالات اعضاى هيئت علمى دانشخاه علوم يزشـكى همــــان

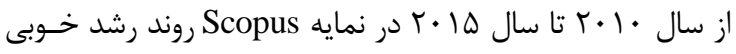

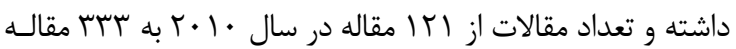

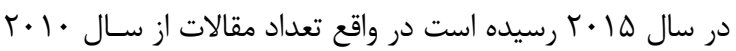

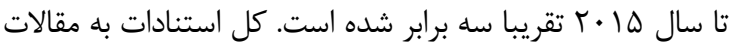

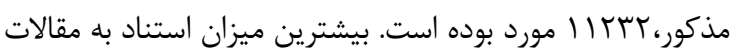

همدان بر اساس مقالات علمى نمايه شده در پايگًاه استنادى Scopus

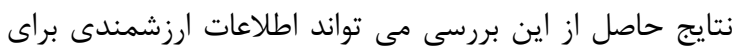
برنامه ريزى و سياست كذارى هاى آتى دانشگاه علوم يزشكى إنى

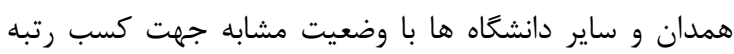

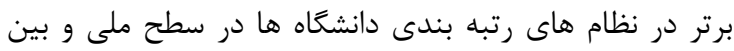

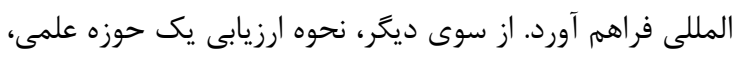

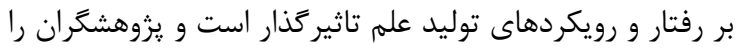

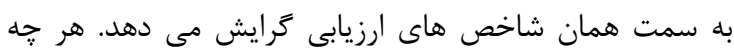

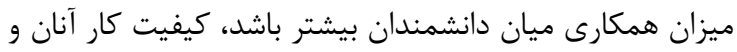

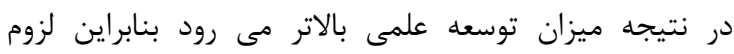

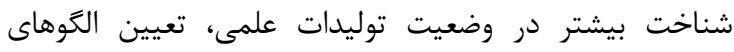

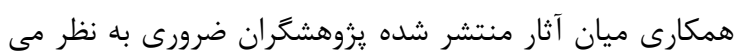

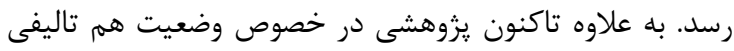

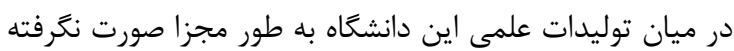
است. اين يزوهش مى تواند جشم انداز بهترى نسبت به به انواع

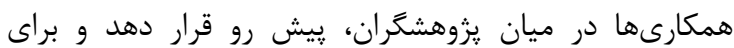

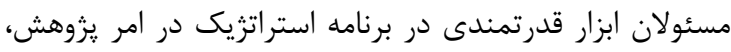
توسعه و ظرفيت سازى براى برنامه هاى آتى فراهم كند.

\section{مواد و روشها}

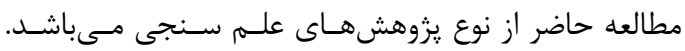

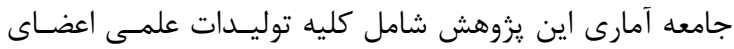

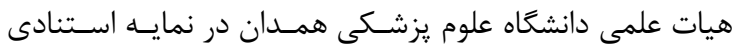
Scopus

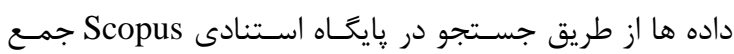

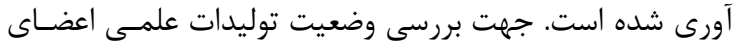

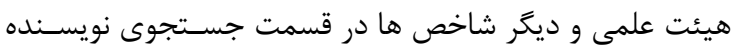

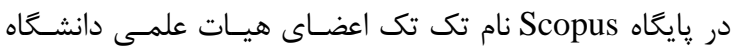

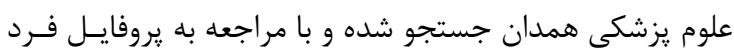

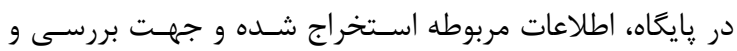

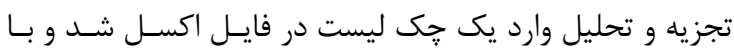
استفاده از فرمول CC، ضريب همكارى، ابتدا براى تك تك سال

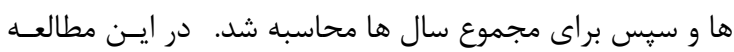

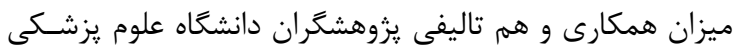
همدان بر اساس وابستخى سازمانى تفكيكى و مورد بررسى قـر هـرار كرفته است. فرمول ضريب همكارى عبارت است از:

$C C=\frac{1-\sum_{j=1}^{k}\left(\frac{1}{j}\right) f j}{\mathrm{~N}}$

تعداد نويسندگان مشاركت كننده در توليد يك مدرك :J 


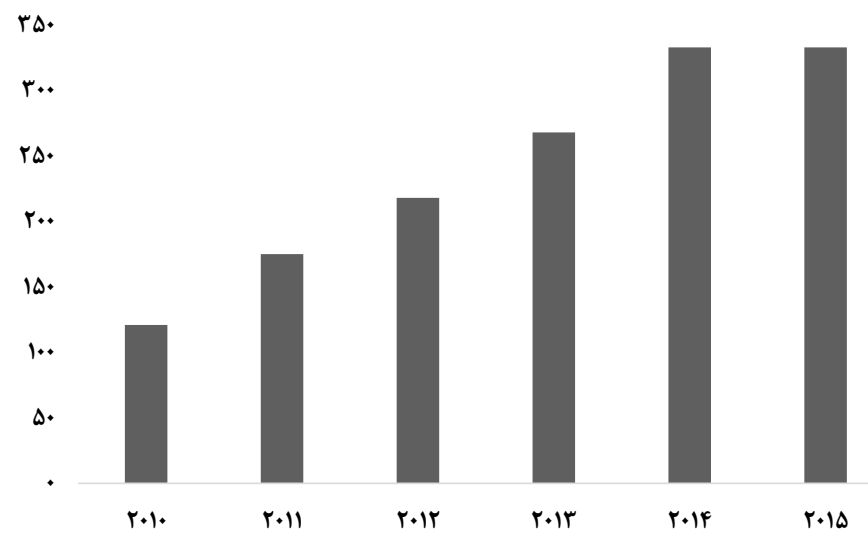

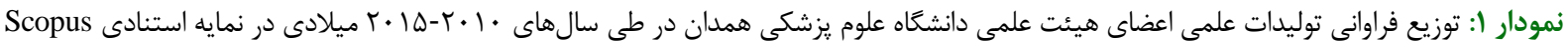

بررسى همكسارى گروهى و ضـريب همكـارى يزوهشــران

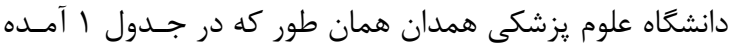

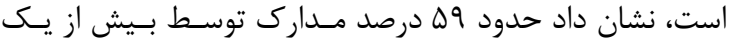

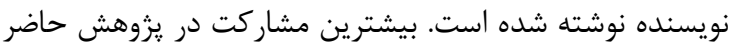

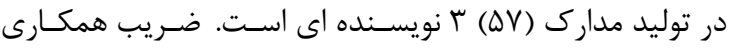
ا كه هر دو مقياس درجه همكارى و شـاخص همكـارى راى (CC)

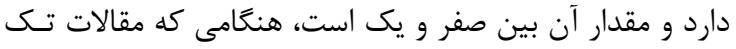

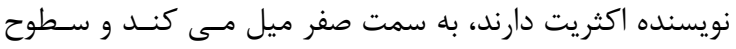

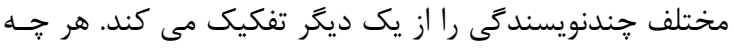

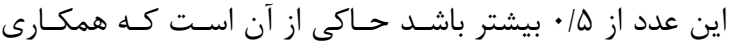
كروهى بين نويسند

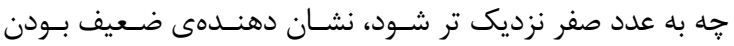

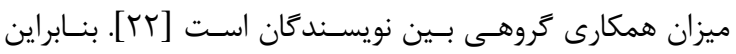

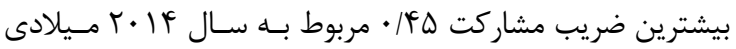

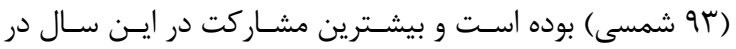

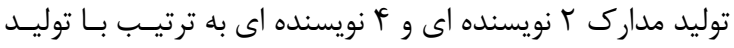
كو ه مل مدرك است. در كل ضريب مشاركت در بازه زمانى مورد

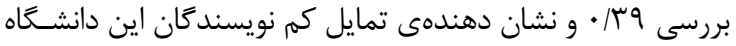

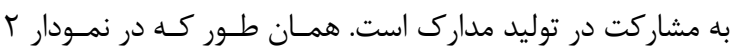

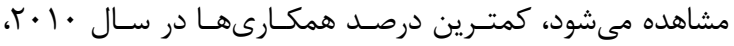

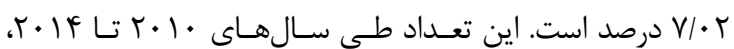

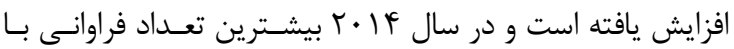

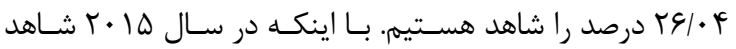

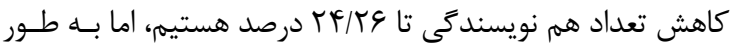

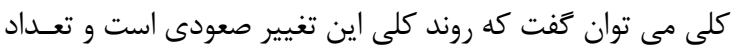
همكارى ها طى سال هاى مورد بررسى افزايش يافته است.

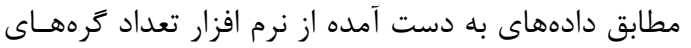

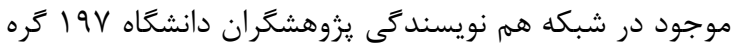

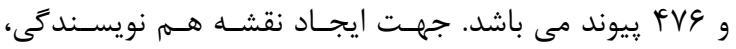

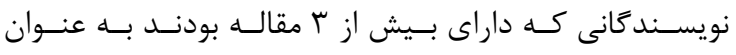

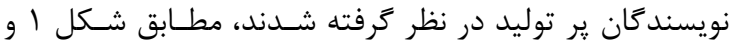

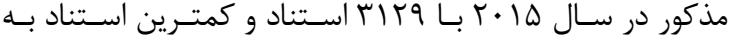

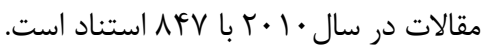

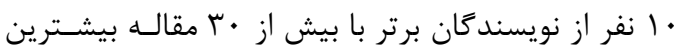

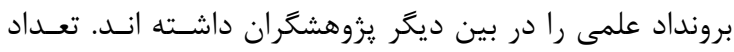

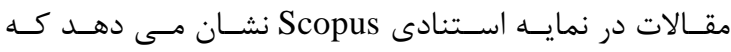

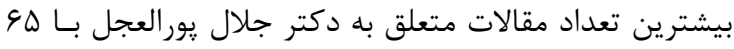

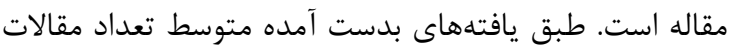

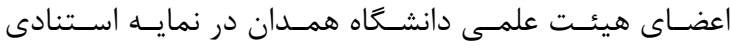
مقاله مى باشد و تعداد زيادى از اعضا داراى الى الى د S Scopus

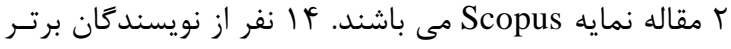

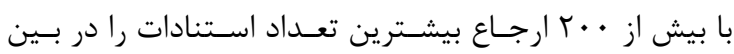

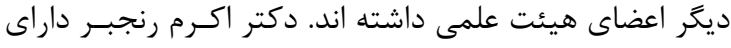

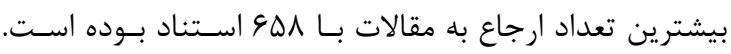

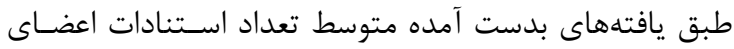

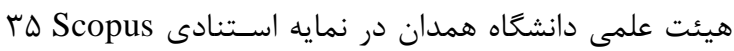

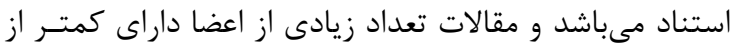

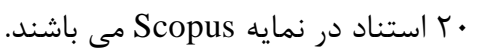

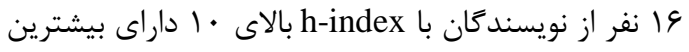

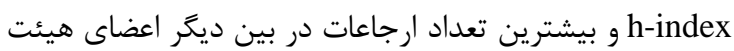

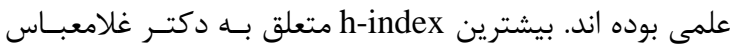

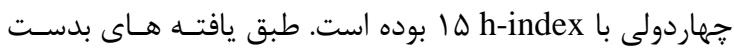

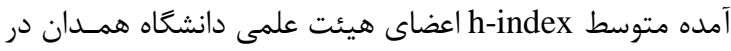

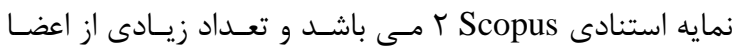

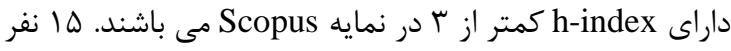

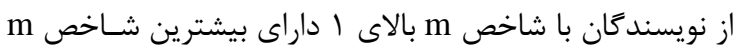

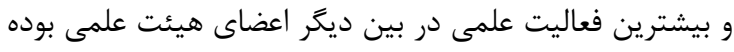

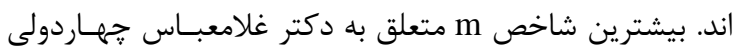

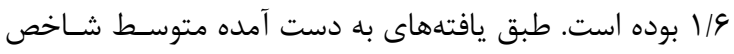

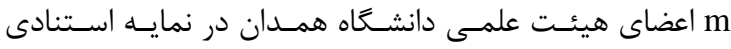
أ Scopus كمتر از ا در نمايه Scopus m مى باشند 
جدول ا: توزيع فراوانى همكارى كروهى و ضريب همكارى يزوهشكران دانشكاه علوم يزشكى همدان براساس مقالات نمايه شده در نمايه استنادى

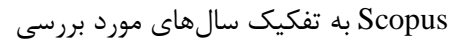

\begin{tabular}{|c|c|c|c|c|c|c|c|c|c|c|c|c|c|c|}
\hline \multirow{2}{*}{ ضمكاري } & \multirow{2}{*}{ درصد } & مجموع & \multicolumn{11}{|c|}{ تعداد مولف } & \multirow{2}{*}{ سال } \\
\hline & & توليدات علمى & 11 & 1. & 9 & $\wedge$ & $\checkmark$ & 9 & $\Delta$ & $p$ & $r$ & r & 1 & \\
\hline זس/. & $\Lambda / \Gamma \wedge$ & $|r|$ & · & · & . & - & r & $\cdot$ & 9 & 1 & TF & 14 & 91 & $r \cdot 1$. \\
\hline$\cdot / \mu F$ & $11 / 9 r$ & IVT & . & . & . & · & 1 & 1 & 9 & $r \Delta$ & r & TF & NT & $r .11$ \\
\hline G & $|\Delta / 1|$ & TIN & . & . & 1 & . & $r$ & $\Delta$ & 19 & 19 & rF & FT & 99 & $r .1 T$ \\
\hline (4) & IN/FT & r\$9 & · & $\cdot$ & 1 & 1 & r & $\Delta$ & 11 & س & et & $\Delta F$ & 119 & $r \cdot I r$ \\
\hline$\cdot / 4 \Delta$ & $r r / \cdot \Lambda$ & אזr & . & . & . & 1 & V & if & rG & $\Delta V$ & $\Delta r$ & GY & r & T.IF \\
\hline . Mt & r & אחזr & 1 & $\cdot$ & - & 1 & $\Lambda$ & $1 \cdot$ & r. & $\Delta V$ & $\Delta \cdot$ & iへ & 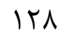 & $r \cdot 10$ \\
\hline$\cdot / 4 q$ & $1 \cdots$ & IfFT & 1 & . & r & r & זr & ro & 91 & $r \cdot 1$ & פד & TFF & $\Delta 99$ & مجموع \\
\hline
\end{tabular}

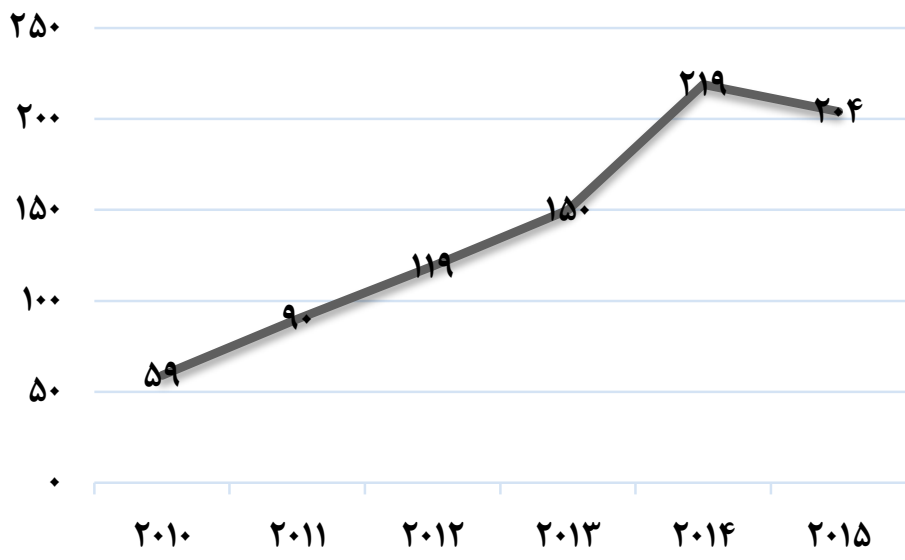

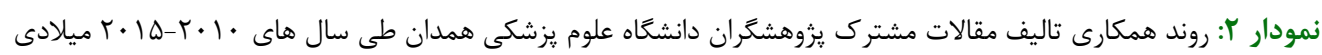

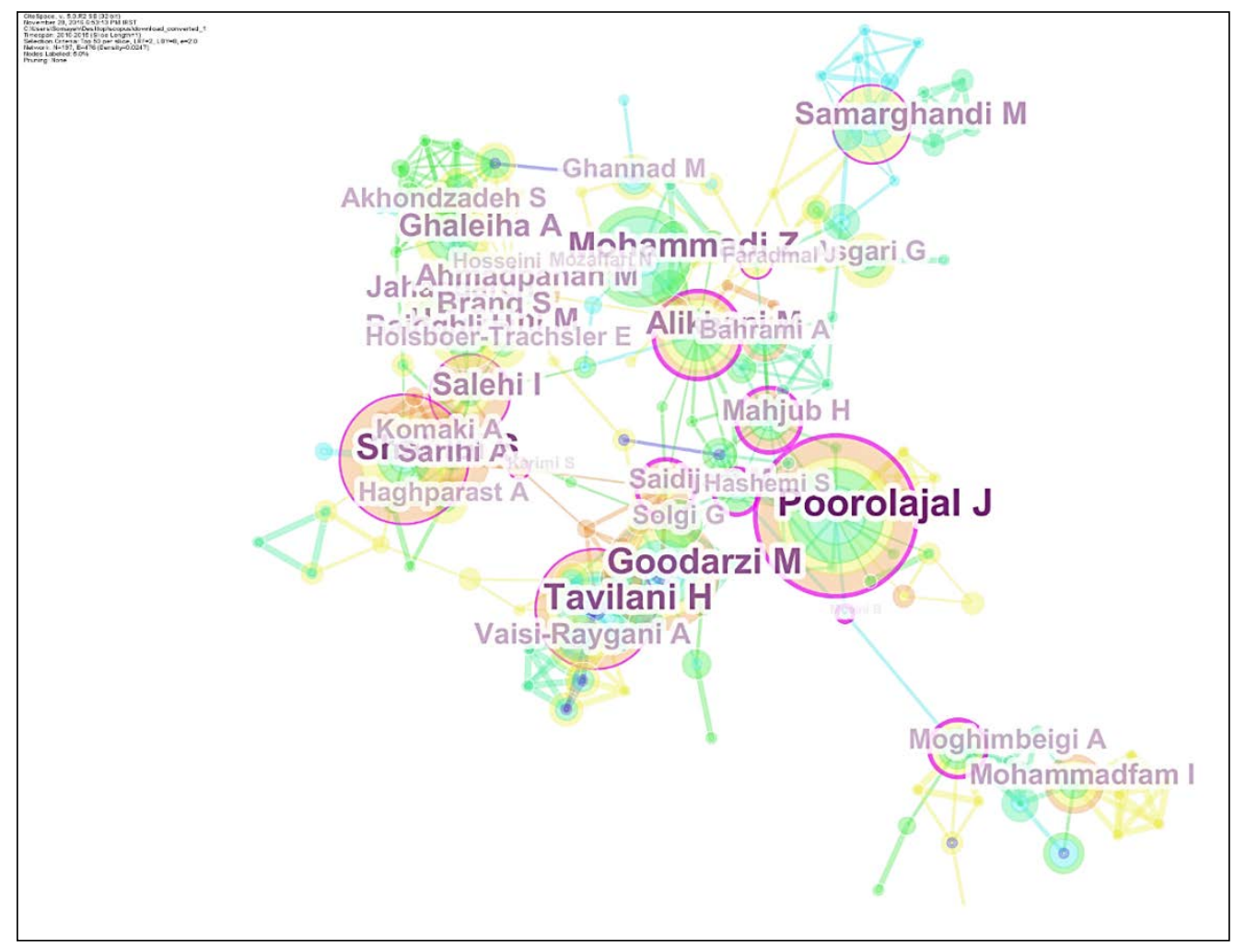

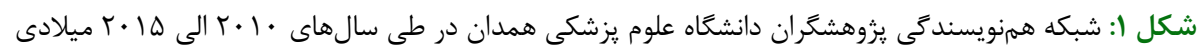


بهداشت و يزشكى مى باشد. به طور ميانگين در اين شبكد، هـر

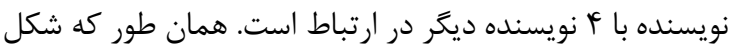
r نشان مى دهد ميزان همكارى در توليدات علمى در طى سلى سال

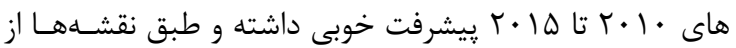

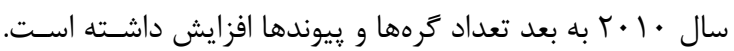

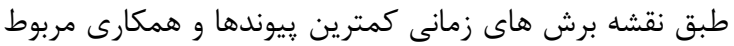

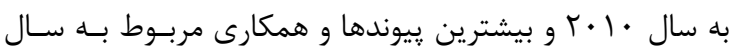

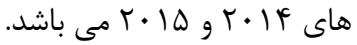

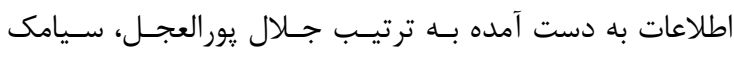

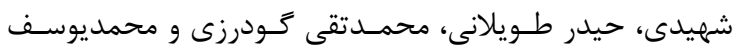

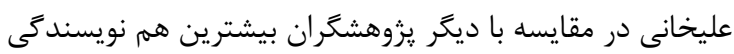

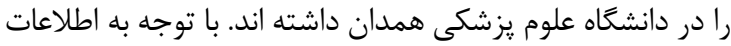

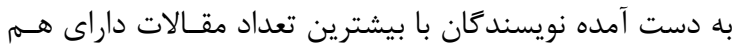

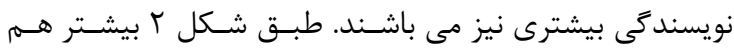

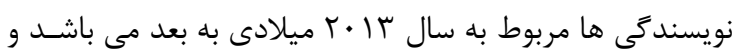

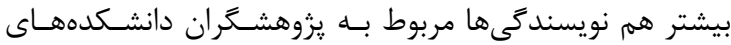

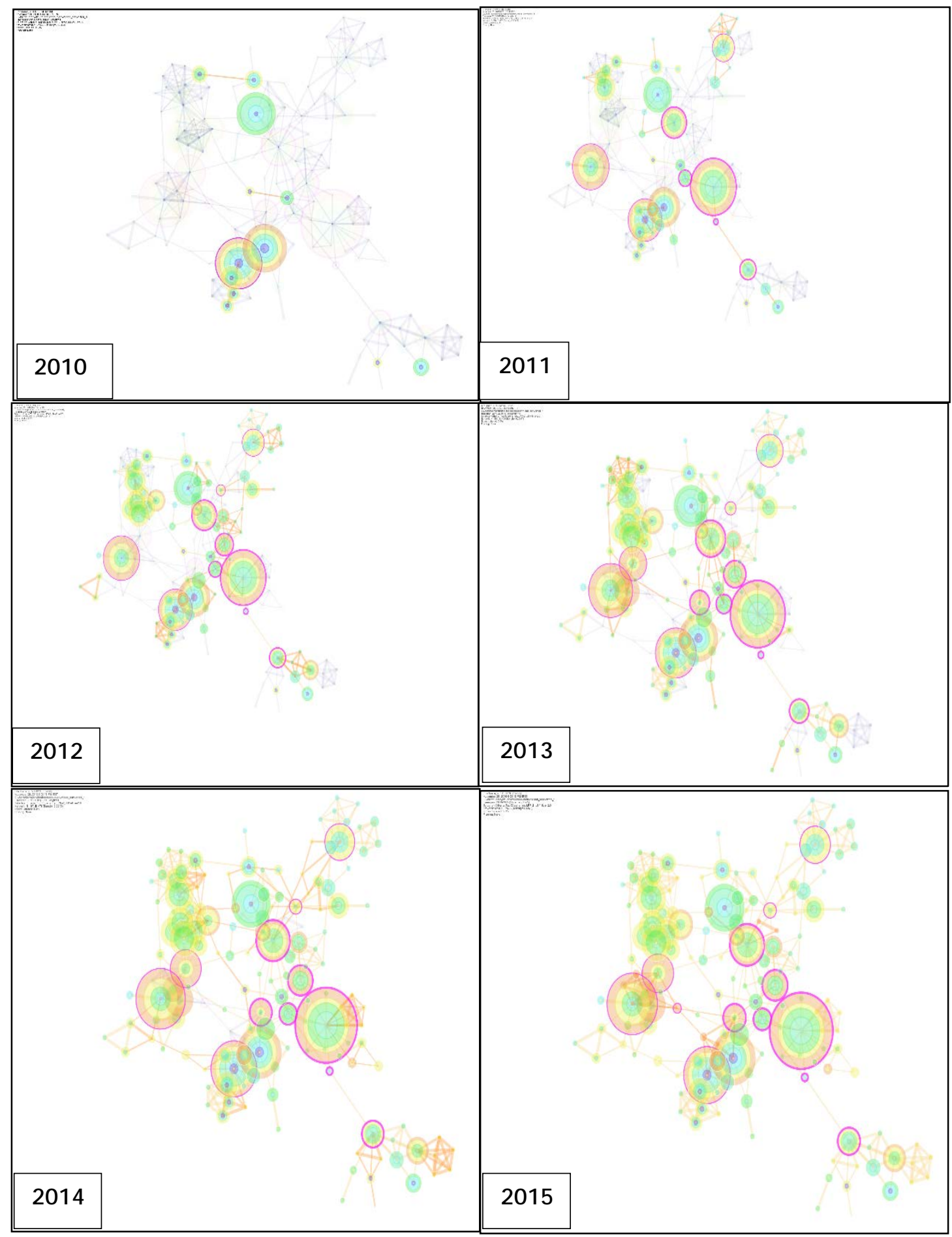

شكل ץ: شبكههاى همنويسندكى به تفكيك برشهاى زمانى 
كار كاه هاى توانمندسازى اعضاى هيئت علمسى در زمينـه هـاى

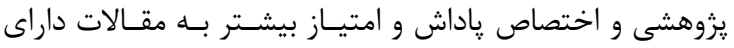

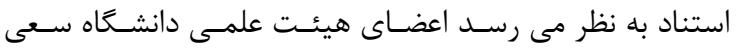
بيشترى در نكارش مقالات با كيفيت و به روز داشته اند.

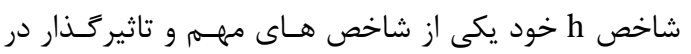

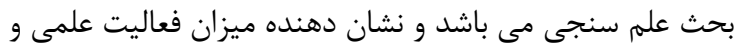

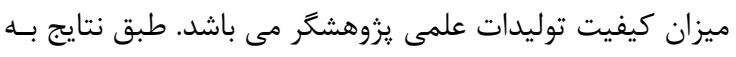
دست آمده شاخص h اعضاى هيئت علمى دانشخاه علوم يزشكى لونى

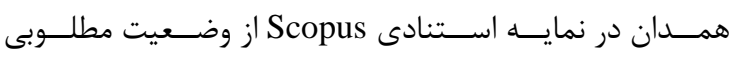

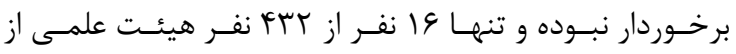

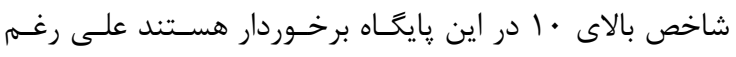
افزايش تعداد استنادات هنوز مقــدار شـاخص h در ايـن پايــاهـاه

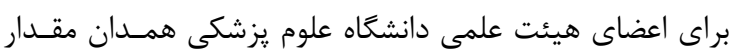

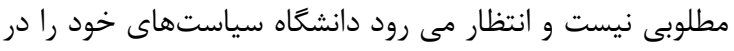
جهت افزايش ميزان استنادات و افزايش كيفيت مقالات تغيير و

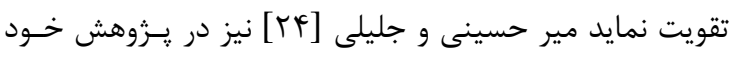

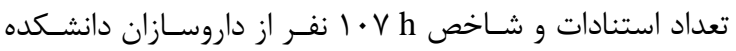

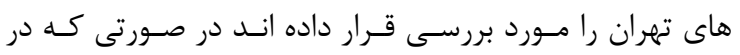

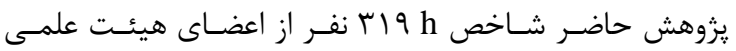

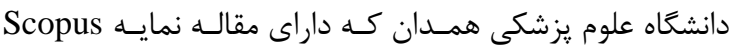

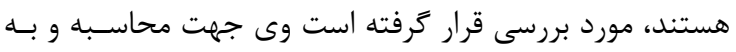

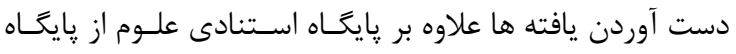

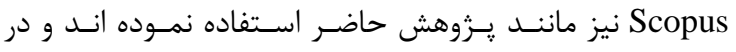

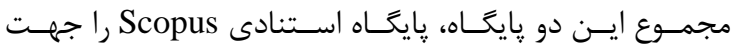

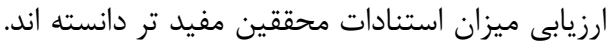

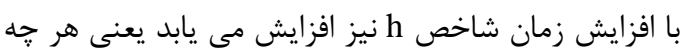

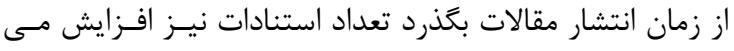

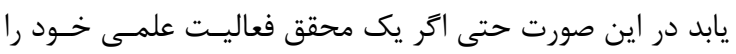

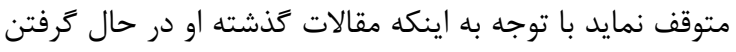

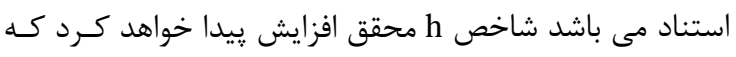

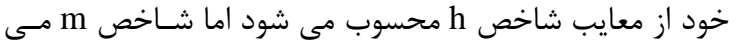

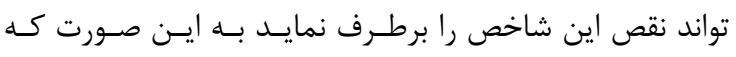

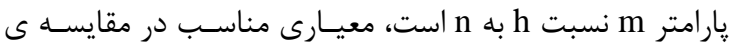

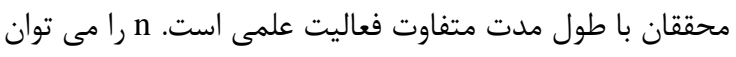
فاصله ى بين مدت زمان نشر اولين مقالهى داراى استناد محقق مدان مدان

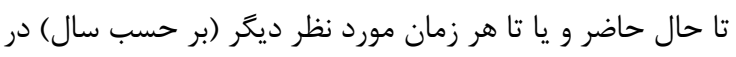

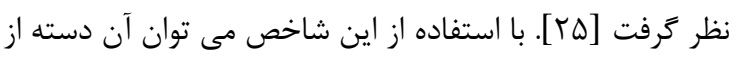

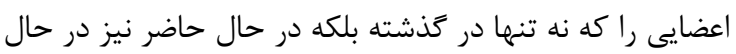

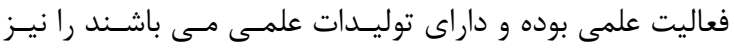

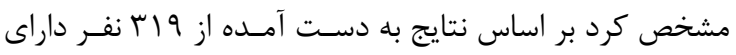

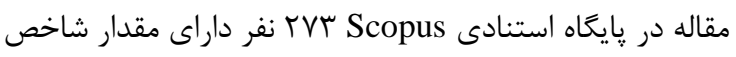

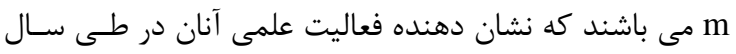

در كشور ما توليد دانش يكى از فعاليتهاى مهرم دانشـعاه-

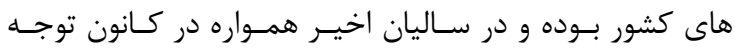

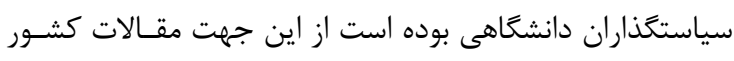

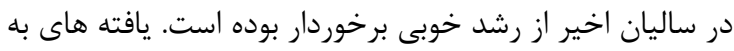

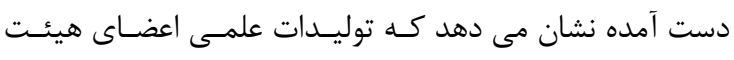

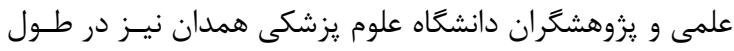

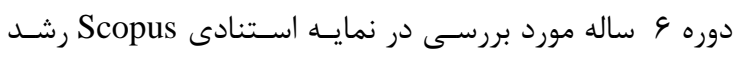

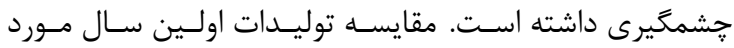

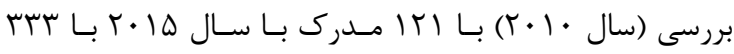

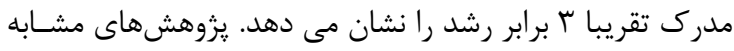

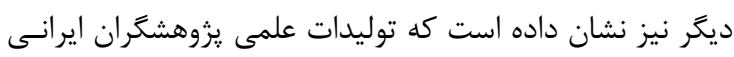

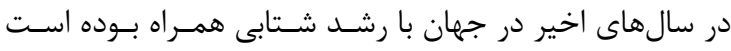

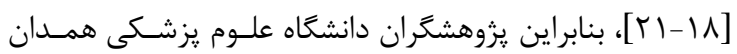

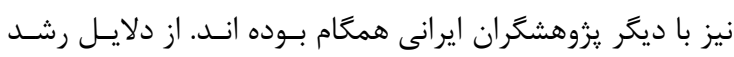

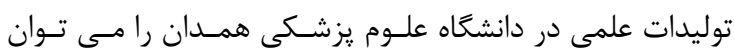

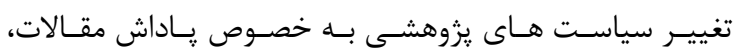

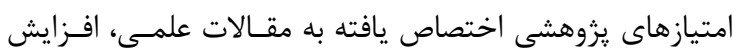

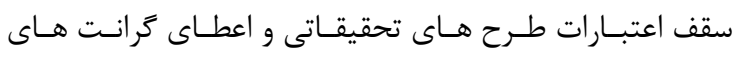

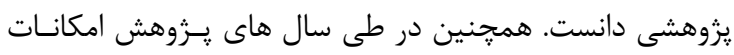

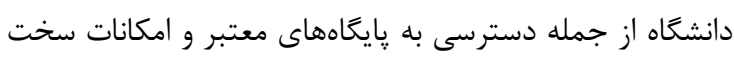

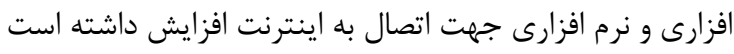

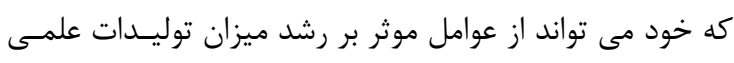

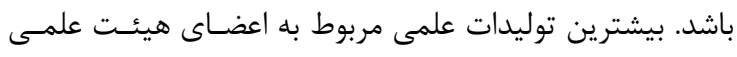

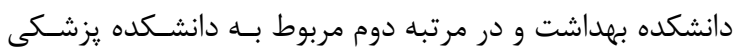

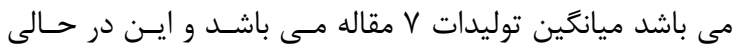

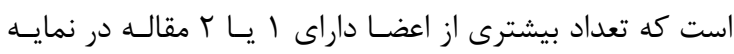

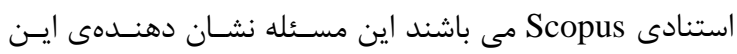

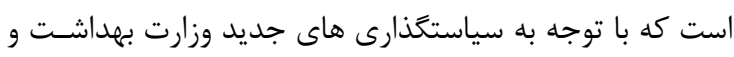

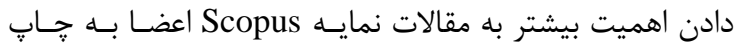

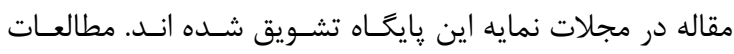

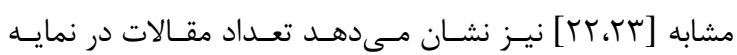
Scopus

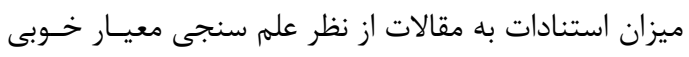

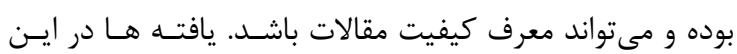

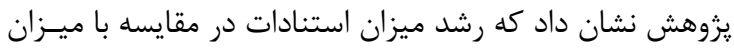

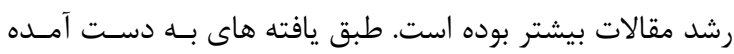

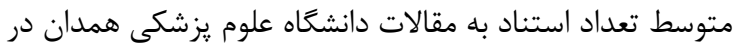

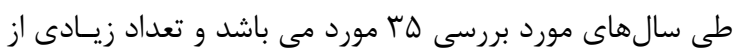

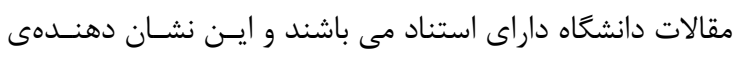

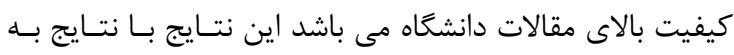
دست آمده در مطالعه فروغى و همكاران [19] مطابقت دارد. بـانـا

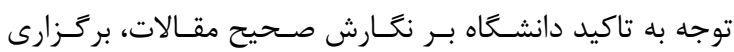


اى در دانشعاه صنعتى شريف يِيوسته در حسال كـاهش بـوده و

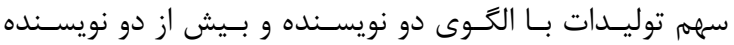

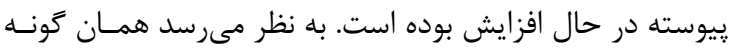

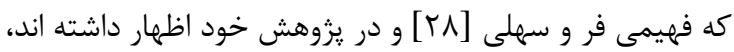

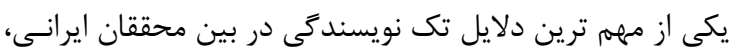
امتياز آن در ارتقاء و يا شركت در مصاحبه هائ هاى مختلف باشد.

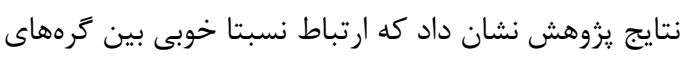

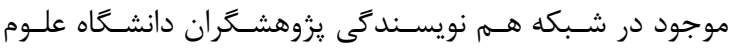

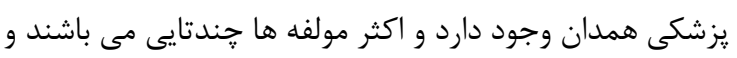

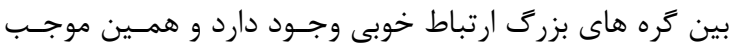

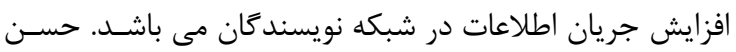

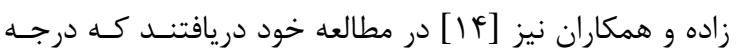

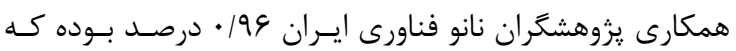

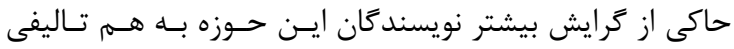

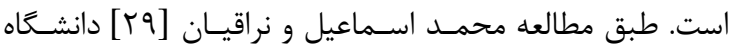

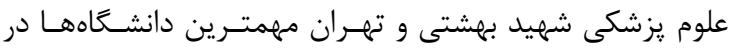

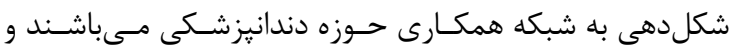
ضريب همكارى براى اين حوزه از وضـعيت مطلـوبى برخـوردار

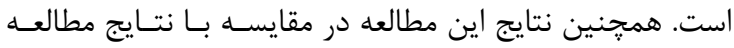
سهيلى و عصاره [19] رابطه عكس دارد. طبـق مطالعـه حاضـر

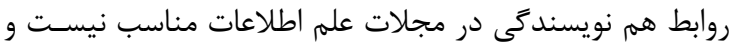

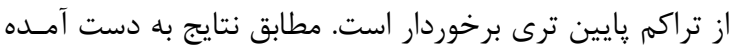

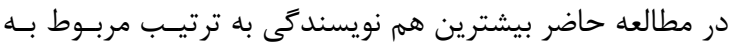

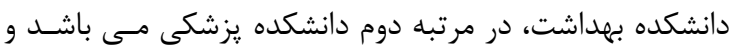

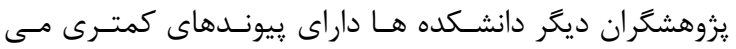

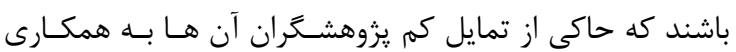

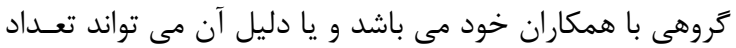

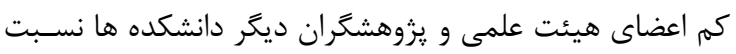

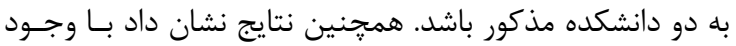

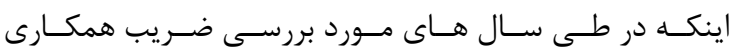

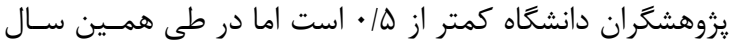

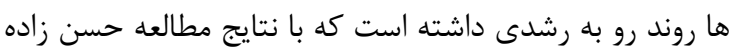

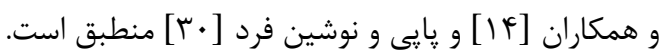

\section{نتيجه تيرى}

در طول دوره يزوهش، توليدات علمى دانشگاه علوم يزشكى همدان از رشد مناسبى برخوردار بوده است اما اين رشد بيشـتر

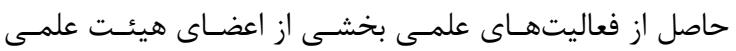

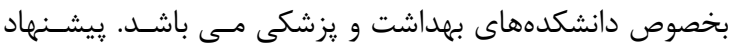

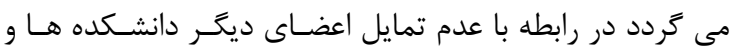

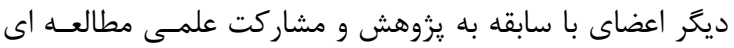

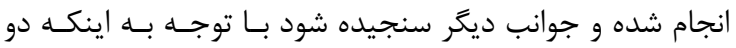

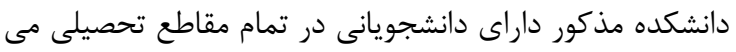

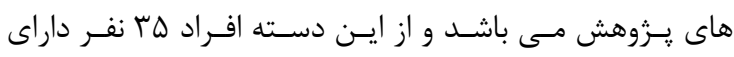

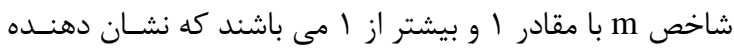

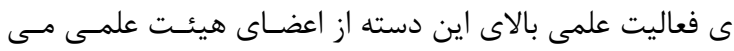

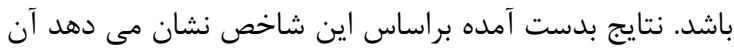

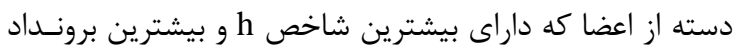

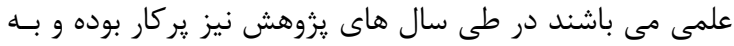

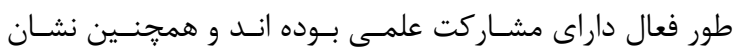

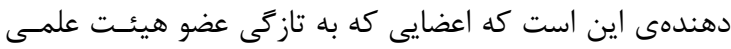
دانشگاه شده اند در مقايسه با برخى از اعضاى إنى با سابقه فعال تـر

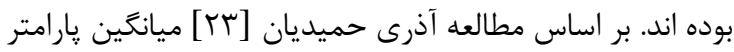

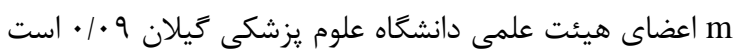

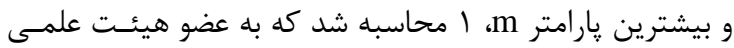

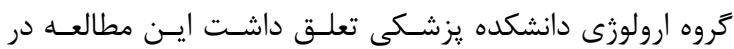

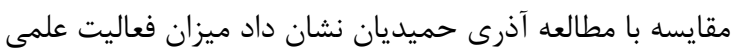

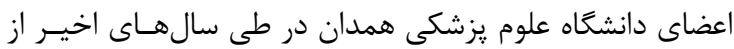
رشد بالايى برخوردار بوده است.

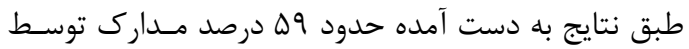

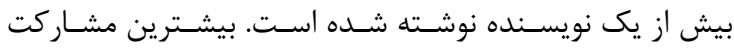

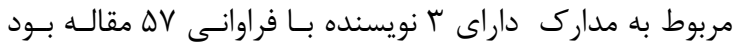

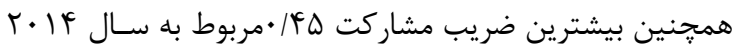
ميلادى (سو شمسى) بوده است و بيشـترين مشـاركت در در ايسن

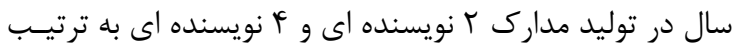
با توليد كو وV مدرك است. در كل ضريب مشـار كت در بـازه

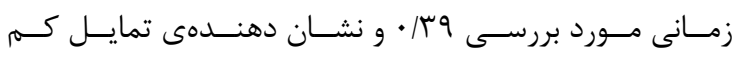

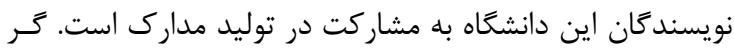

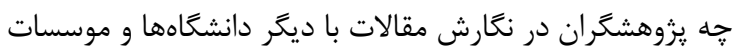

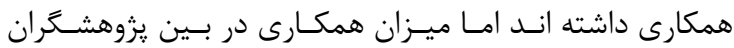

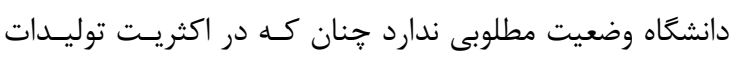

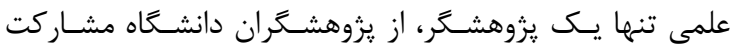

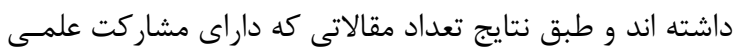

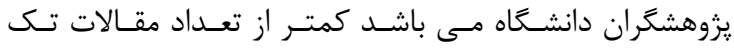

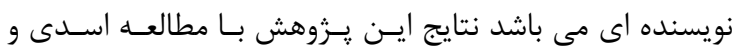

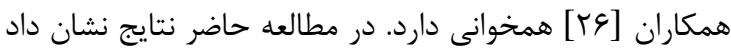

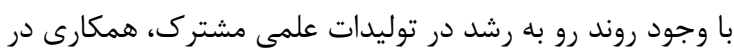

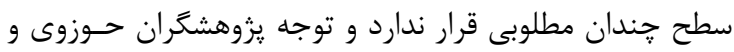

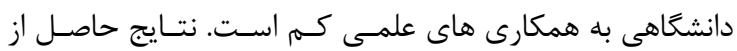

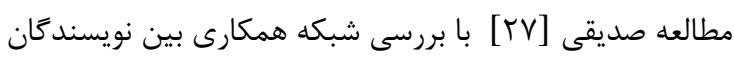

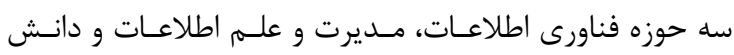
شناسى نشان داد كه ميزان شاخص درجه تراكم و نيـز انسـجام

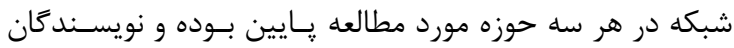

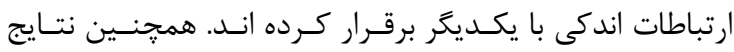

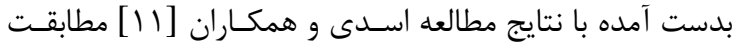

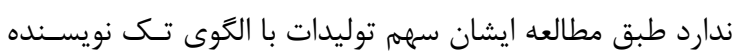


همكارى يزوهشكَران هم رشته و هم تخصص و حتى استفاده از

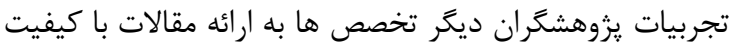

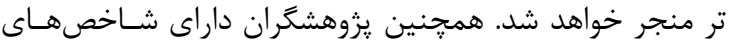

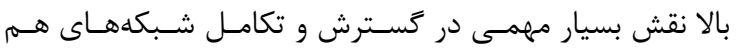

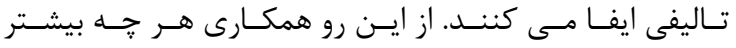

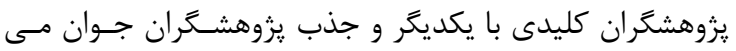

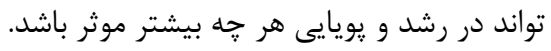

$$
\begin{aligned}
& \text { تشكر و قدرواذى } \\
& \text { از معاونت آموزشسى دانشـعاه جهـت در اختيـار قـرار دادن }
\end{aligned}
$$

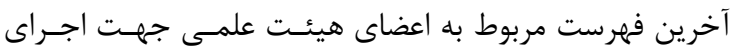

$$
\begin{aligned}
& \text { مطالعه حاضر تشكر و قدردانى مى شود. }
\end{aligned}
$$

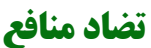

اين مطالعه براى نويسنده هيجزَّونه تضـاد منــافعى نداشـته

\section{REFERENCES}

1. Chalaki A, Nourmohammadi H. Vaziri E. Etemadifard A. Scientific production of iran in 2005 and 2006 on ISI database. National Studies on Librarianship and Information Organization. 2007;71:71-90. (Persian)

2. Janmohammadi N, Yaminfirooz M. Nooshinfard F. Iran's scientific production in orthopaedic field: A Scientometric Study. Iranian Journal of Orthopaedic Surgery (IJOS). 2012;10:81-6. (Persian)

3. Priem J, Hemminger BH. Scientometrics 2.0: New metrics of scholarly impact on the social Web. First Monday. 2010;15(7).

4. Mahmoumi J, Nikzad H. Nikzad M. Studies assessing medical research: the status and future direction. Researches of the second National Conference on research and development in the field of medical science; November 22; babol university of medical sciences 2010. (Persian)

5. NorouziChakali A, MollaMohammadi J.Gh. Comparative evaluation of documents Islamic Azad University indexed in Scopus databases in 2007 and 2008 years. Epistemology. 2011;3(12):83-98.

6. Damarchiloo M. Hirsch index and complementary indicators. Tehran: Chapar; 2014.

7. Egghe l. Theory and practice of the g-index. Scientometrics. 2006;9(1):131-52.

8. NorooziChakoli A, Aghayari H. Hasanzadeh M. .Assessment Shahid Beheshti University of medical science researchers in databases ISI, Scopus and Google Scholar According to h-index,g and $\mathrm{m}$ parameter. Library and Information Research Journal. 2011;1(1):135-152. (Persian)

9. NorooziChakoli A. Introduction to Scientometric. Tehran: Samt; 2013. (Persian)

10. Fatahi R, Danesh F, Soheli, F. Evaluation International status of Ferdowsi University of Mashhad scientific publications during 1990 and 2010 in the Web of Science with the aim of mapping of Science the university. Library and Information Research Journal. 2011;1(1):175-96. (Persian)

11. Asadi M, Joulaei S, Saqafi S, Bazrafshan A. Scientific collaborations and co-authorship networks in scientific publications of sharif university of technology during 20052010. National Studies on Librarianship and Information Organization. 2013;24(1):166-86. (Persian)

12. Soheili F, Osareh, F, Farajpahloo A. .Social network analyses of information science researchers co-authorship. Journal of Information Processing and Management.
باشند ممكن است اين موضوع بر تعداد مقالات دانشـكده هـاى

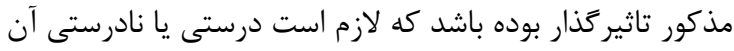

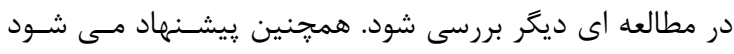

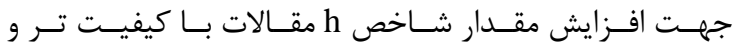

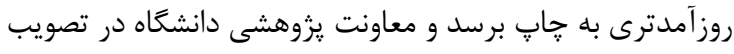

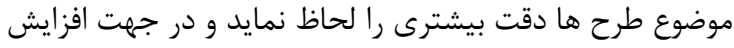

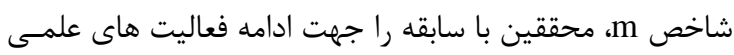
تشويق نموده و دلايل نزول علمى آنان را شناسايى و رفع نمايد. همجنين لازم است يزوهشكران دانشكده ها به همكارى و و تبادل

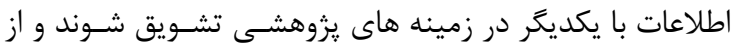

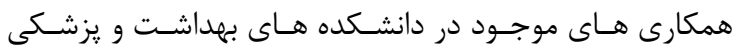

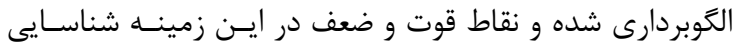

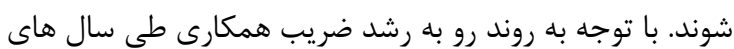

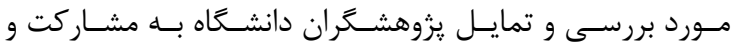

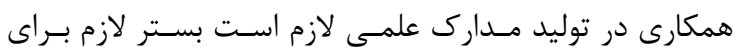
مشاركت گسترده تر يزوهشــران دانشـعاه فـراهم شـود، قطعـا

2013;29(1):191-210.

13. Baji F, Osareh F. An investigation in to the structure of the co-authorship network of neuroscience field in Iran, using a social network analysis approach. Studies on Library \& Information Science 2013;21(2):53-70

14. Hassanzadeh M, Khodadust R, Zandian F. Analysis of coauthorship indicators, between's centrality and structural holes of the Iranian nanotechnology researchers in science citation index (1991- 2011). Information Processing Management 2012;28(1):223-49. (Persian)

15. Zangishe E, Soheili F, Ahmadi H. Citation analysis and coauthorship in the field of Quranic sciences researchers in "Web of Science" Database and mapping the scientific structure of this discipline between the 1993-2012 years. Journal of Scientometrics. 2013;1(1):63-80. (Persian)

16. Soheili F, Osareh F. A Survey on density and sizeof coauthorship networksin information science journals. Iranian Research Institute Iranian for Science and Technology. 2014;29(2):351-72. (Persian)

17. Singhal K, Banshal SK, Uddin A, Singh VK. A scientometric analysis of computer science research in India. InContemporary Computing (IC3) Eighth International Conference; August 20;India 2015.

18. Ajiferukei B, Tague J. Collaborative coefficient: a single measure of the degree of collaboration in research. Translated by Farajphalu A. Information Sciences and Technology. 2007;23(1-2):175-810.

19. Foroughi F, Hamzehee K, Foroughinia A, Najafi F, Khodarahmi R, Saleki A. Seventeen years of science production among researchers of Kermanshah University of Medical sciences (1995-2011) based on Web of Science (WOS). Journal of Kermanshah University of Medical Sciences. 2012;16(7):549-6. (Persian)

20. Osareh F, NorouziCHakoli A, Keshvari M. Co-authorship of Iranian researchers in science, social science, art and humanities citation indexes in the web of science between 2000 and 2006. Journal of Information Processing and Management 2010;25(4):573-95. (Persian)

21. Hassanzadeh HM, Gorji H, Shokranehnanehkaran F, Valinejadi A. Scientific products of Iran University of Medical Sciences'authors with co-authorship networks in web of science(WOS) database, up to 2007. Journal of Health Administration. 2009;11(34):59-67. (Persian)

22. Sobhani AR, Tabari R, Tayefeh N. The article publication status among fFaculty members of Guilan University of 
Medical Sciences. Journal of Guilan University of Medical Sciences. 2009;18(70):80-6. (Persian)

23. Azari-Hamidian S. Scientific research output of faculty members of Guilan University of Medical Sciences using the Hirsch Index (h Index) and $\mathrm{m}$ parameter by the end of 2012. Journal of Guilan University of Medical Sciences. 2013;22(86):12-23. (Persian)

24. Mirhosseini Z, Jalilibaleh M. Investigation of the research output of faculty members of Tehran pharmacy colleges according to h-index factor. Epistemology. 2009;2(2):85100. (Persian)

25. Mashatan M, Pouresmaeil M, Malekifard E, Asefzadeh S. The trend of scientific production in Qazvin University of Medical Sciences based on Web of Science, Pub Med and Scopus databases (2007-2012). Journal of Qazvin University of Medical Sciences. 2014;17(6):53-9.

26. Asadi S, Aghamollaee F, Malakooti Khah F. Co-authorship collaboration between the scholars of tehran universities and qom seminary (Howzeh) During 2004-2013. Iranian journal of culture in the islamic university. 2016;5(17):493-514. (Persian)

27. Sedighi M. Analysis of the status of Iranian scientific production in some subject areas by scientometric and social network analysis indicators. Journal of Information Processing and Management. 2017;32(4):967-88. (Persian)

28. Fahimifar S, Sahli F. Co-authorship network in scientific knowledge and information science persian journals. Research on Information Science \& Public Libraries. 2015;21(1):127-51.

29. MohammadEsmaeil S, Naraghian N. co-authorship maping in the field of dentistry. Health Information Management. 2017;14(6):249-254. DOI: 10.22122/him.v14i6.3321

30. Papi Z, Nooshinfard F, Co-authorship of iranian researchers in the field of toxicology in institute for scientific information (ISI) during 1991-2011. Health Inf Manage 2014;11(1):59 